\title{
Bovicin HC5 and nisin reduce Staphylococcus aureus adhesion to polystyrene and change the hydrophobicity profile and Gibbs free energy of adhesion
}

\author{
Natan de Jesus Pimentel-Filho a , Mayra Carla de Freitas Martins ${ }^{\text {b }}$, Guilherme Bicalho Nogueira ${ }^{\text {a }}$, \\ Hilário Cuquetto Mantovani ${ }^{\text {, }}$ Maria Cristina Dantas Vanetti ${ }^{\text {a,* }}$ \\ a Departamento de Microbiologia, Universidade Federal de Viçosa, Av. P.H. Rolfs, 36570-000 Viçosa, Brazil \\ b Departamento de Ciência e Tecnologia de Alimentos, Universidade Federal de Viçosa, Av. P.H. Rolfs, 36570-000 Viçosa, Brazil
}

\section{A R T I C L E I N F O}

\section{Article history:}

Received 7 March 2014

Received in revised form 1 August 2014

Accepted 2 August 2014

Available online 9 August 2014

\section{Keywords:}

Staphylococcus aureus

Food-contact surface

Hydrophobicity

Foodborne pathogen

\begin{abstract}
A B S T R A C T
Staphylococcus aureus is an opportunistic pathogen often multidrug-resistant that not only causes a variety of human diseases, but also is able to survive on biotic and abiotic surfaces through biofilm communities. The best way to inhibit biofilm establishment is to prevent cell adhesion. In the present study, subinhibitory concentrations of the bacteriocins bovicin HC5 and nisin were tested for their capability to interfere with the adhesion of $S$. aureus to polystyrene. Subinhibitory dosages of the bacteriocins reduced cell adhesion and this occurred probably due to changes in the hydrophobicity of the bacterial cell and polystyrene surfaces. After treatment with bovicin HC5 and nisin, the surfaces became more hydrophilic and the free energy of adhesion $\left(\Delta G_{\text {adhesion }}\right)$ between bacteria and the polystyrene surface was unfavorable. The transcriptional level of selected genes was assessed by RT-qPCR approach, revealing that the bacteriocins affected the expression of some important biofilm associated genes ( $\mathrm{icaD}$, $\mathrm{fnbA}$, and $\mathrm{clfB}$ ) and rnalII, which is involved in the quorum sensing mechanism. The conditioning of food-contact surfaces with bacteriocins can be an innovative and powerful strategy to prevent biofilms in the food industry. The results are relevant for food safety as they indicate that bovicin HC5 and nisin can inhibit bacterial adhesion and consequent biofilm establishment, since cell adhesion precedes biofilm formation.
\end{abstract}

(C) 2014 Elsevier B.V. All rights reserved.

\section{Introduction}

Staphylococcus aureus is a common human pathogen responsible for food-borne intoxications worldwide, caused by the ingestion of food containing staphylococcal heat-stable enterotoxins (Le Loir et al., 2003). Because $S$. aureus does not compete well with indigenous microbiota in raw foods, contamination is mainly associated with improper handling of cooked or processed foods, followed by storage under conditions which allow the growth of $S$. aureus and production of the enterotoxin (Argudín et al., 2010). Another pathway leading to cross contamination of foods is the capability of some strains to develop biofilms on food-processing surfaces (Vázquez-Sánchez et al., 2013).

Biofilms allow bacteria to better resist the application of external stress stimuli such as desiccation, UV light, and treatment with antimicrobial and sanitizing agents, due to low metabolic activity of cells, phenotypic variability and low diffusion of antimicrobials (Herrera et al., 2007; Parsek and Fuqua, 2004).

\footnotetext{
* Corresponding author at: Departamento de Microbiologia, Universidade Federal de Viçosa, Av. P.H. Rolfs, Viçosa, MG 36570-000, Brazil. Tel.: +55 3138992954

E-mail address: mvanetti@ufv.br (M.C.D. Vanetti).
}

Biofilm formation depends on the characteristics of the surface, the bacterial cell, the growth medium, the optical density and other environmental conditions (Donlan and Costerton, 2002). There are several mechanisms by which microbial species are able to come into closer contact with a surface, attach firmly to it, promote cell-cell interactions and grow as a complex structure (Bryers and Ratner, 2004). Adhesion is the initial step in biofilm formation which is mediated mainly by non-specific long-range attractive Lifshitz-van der Waals forces and electrostatic, acid-base, and hydrophobic interaction forces (Busscher et al., 2010; Chung et al., 2014). Properties of the cell surface, particularly the presence of extracellular appendages, the interactions involved in cell-cell communication, and exopolysaccharide production are important for biofilm formation and development (Hori and Matsumoto, 2010; Simões et al., 2010).

Stainless steel is the most frequently used material for foodprocessing equipments. Polymers are another food-contact surface material widely used in the food industry, mainly for packaging. The most commonly used plastics in packaging industry are based on petrochemical products such as polyethylene terephthalate, polyvinyl chloride, polyethylene, polypropylene, polystyrene, and polyamide (Mahalik and Nambiar, 2010). Surface properties, such as hydrophobicity, 
roughness, and a predisposition to protein adsorption, are recognized as important for attachment of microorganisms to surfaces and the subsequent biofilm development (Araújo et al., 2009; Palmer et al., 2007). The hydrophobicity of the surfaces contributes to the water removal. If two surfaces are hydrophobic, it is easier to eliminate the water layer, because the molecules of surfaces have less attraction to water molecules and higher interaction with themselves (Araújo et al., 2009).

In staphylococcal species, the development of biofilms is mainly facilitated by polysaccharide intercellular adhesin (PIA), a glycan of $\beta$ 1,6-linked 2-acetamido-2-deoxy-D-glucopyranosyl residue of which $15 \%$ is non- $N$-acetylated (Rohde et al., 2010). The polysaccharide is synthesized by enzymes encoded by the icaADBC operon. The IcaA, IcaC, and IcaD proteins are located in the membrane fraction; the icaB gene is mainly found in the culture supernatant and deacetylates PIA when it is localized on the cell surface (Gerke et al., 1998). Co-expression of icaA and icaD increases $\mathrm{N}$-acetylglucosaminyltransferase activity and slime production (Arciola et al., 2006; Atshan et al., 2013).

Intercellular signaling, often referred to as quorum sensing, is reported to be involved in biofilm development (Yarwood et al., 2004). S. aureus quorum sensing system is encoded by the accessory gene regulator ( $a g r)$ locus, a global regulatory network of virulence factors including biofilm development. The agr chromosomal locus has two promoters, $\mathrm{P} 2$ and $\mathrm{P} 3$, that control the expression of the divergent RNAII and RNAIII transcripts, respectively. RNAII encodes the core components of the agr system, including the AgrB (transmembrane endopeptidase), AgrD (precursor of the autoinducing peptide), AgrC (histidine kinase), and AgrA (regulator) proteins. The RNAIII transcript is itself the main effector for the agr system and thereby coordinates the upregulation of secreted virulence factors and the downregulation of cell surface proteins involved in the bacterial attachment (Novick and Geisinger, 2008; Pang et al., 2010).

Bacteriocins, ribosomally synthesized peptides produced by bacteria, have been suggested to inhibit the adhesion of pathogens to abiotic surface (Winkelströter et al., 2011). Many of these substances may be useful as antimicrobial agents for practical applications (Fagundes et al., 2011). Nisin, the most well-studied bacteriocin, is a lantibiotic produced by Lactococcus lactis subsp. lactis used in over 50 countries as a food preservative. Bovicin HC5 is a bacteriocin with a broad spectrum of action produced by Streptococcus bovis HC5, isolated from the rumen of cattle (Mantovani et al., 2002). Inhibition of the gram-positive foodborne pathogens S. aureus, Listeria monocytogenes, Bacillus cereus, and Clostridium perfringens by the bacteriocins bovicin HC5 and nisin has been reported (Antolinos et al., 2011; Mantovani and Russell, 2003; Pimentel-Filho et al., 2013; Pimentel-Filho et al., 2014; Solomakos et al., 2008; Udompijitkul et al., 2011). Bacteriocins with anti-staphylococcal activity, such as bovicin HC5, could open new possibilities to prevent adhesion and thus, to control biofilm formation. Highlighting the potential of antimicrobial peptides against biofilms as a current alternative, recent studies have evaluated the effectiveness of bacteriocins such as nisin, lacticin $\mathrm{Q}$, nukacin ISK-1, and enterocin AS-48 against staphylococcal biofilms (Caballero Goméz et al., 2013; Cabo et al., 2009; Davison et al., 2010; Okuda et al., 2013).

Another interesting strategy to control bacterial adhesion and subsequent biofilm formation is to modify the surface by conditioning or incorporating bacteriocins directly on surfaces which are in direct contact with food. Nostro et al. (2010) incorporated different concentrations of nisin in poly-ethylene-co-vinyl acetate (EVA) films, used for food packing, to evaluate their effect on the biofilm-forming ability of L. monocytogenes, S. aureus and Staphylococcus epidermidis. The results revealed the efficacy of EVA/nisin films in reducing biofilm formation on their surfaces with more evident effect for S. epidermidis than L. monocytogenes and S. aureus strains.

In this work we aimed to evaluate the effect of subinhibitory dosages of bovicin HC5 and nisin on the adhesion of $S$. aureus to the polystyrene surface, determine changes on the surface hydrophobicity and free energy of adhesion, and investigate if subinhibitory concentration of the bacteriocins affects the expression rate of genes involved in biofilm formation in the evaluated conditions.

\section{Materials and methods}

\subsection{Bacterial strains and culture conditions}

The bacterial strains used in the present study are shown in Table 1. The bovicin HC5-producing strain S. bovis HC5 was cultivated under anaerobic conditions, at $39{ }^{\circ} \mathrm{C}$ overnight, in basal medium containing (per liter) $0.292 \mathrm{~g} \mathrm{~K}_{2} \mathrm{HPO}_{4}, 0.292 \mathrm{~g} \mathrm{KH}_{2} \mathrm{PO}_{4}, 0.48 \mathrm{~g}\left(\mathrm{NH}_{4}\right)_{2} \mathrm{SO}_{4}, 0.48 \mathrm{~g}$ $\mathrm{NaCl}, 0.1 \mathrm{~g} \mathrm{MgSO}_{4} \cdot 7 \mathrm{H}_{2} \mathrm{O}, 0.064 \mathrm{~g} \mathrm{CaCl}_{2} \cdot 2 \mathrm{H}_{2} \mathrm{O}, 0.5 \mathrm{~g}$ cysteine hydrochloride, $4 \mathrm{~g} \mathrm{Na}_{2} \mathrm{CO}_{3}, 0.1 \mathrm{~g}$ trypticase, and $0.5 \mathrm{~g}$ yeast extract. Glucose $(4 \mathrm{~g} / \mathrm{l})$ was added as a carbon source.

S. aureus strains were grown aerobically with vigorous agitation at $37^{\circ} \mathrm{C}$ in synthetic medium (Gertz et al., 1999).

\subsection{Bacteriocins}

Nisin A from L. lactis (2.5\% nisin, $\geq 1000 \mathrm{IU} / \mathrm{mg}$; Sigma-Aldrich, Germany) was resuspended in sterile sodium phosphate buffer (10 mM, pH 7.2) and stored at $7{ }^{\circ} \mathrm{C}$ until use.

Extract of bovicin HC5 was prepared as described by Mantovani et al. (2002). Briefly, stationary-phase S. bovis HC5 was harvested by centrifugation and the cells were washed in sodium phosphate buffer $(10 \mathrm{mM}$, $\mathrm{pH} 7.2)$. The cell pellet was re-suspended in acidic $\mathrm{NaCl}(100 \mathrm{mM}, \mathrm{pH}$ 2.0) for $2 \mathrm{~h}$ at room temperature (Mantovani et al., 2002). The suspensions were centrifuged to remove cells and the cell-free supernatant was lyophilized. The lyophilized material was suspended in sterile sodium phosphate buffer (10 mM, pH 2.0). Purification of bovicin HC5 was performed by reversed-phase high-performance liquid chromatography (RP-HPLC) using a semi-preparative column (Shimadzu C18, Japan; length, $150 \mathrm{~mm}$; inner diameter, $4.6 \mathrm{~mm}$; particle size, $5 \mu \mathrm{m}$ ). The column was equilibrated with buffer A ( $0.1 \%$ trifluoroacetic acid [TFA] in water), and the peptide was eluted using a linear gradient of 35 to $50 \%$ buffer B ( $80 \%$ acetonitrile, $0.1 \%$ TFA in water) at $22{ }^{\circ} \mathrm{C}$ and at a flow rate of $1 \mathrm{ml} / \mathrm{min}$. The absorbance was monitored at 214 and $280 \mathrm{~nm}$, and the eluted fraction corresponding to pure bovicin HC5 was lyophilized (Paiva et al., 2011). Bacteriocin stock solutions were stored at $7{ }^{\circ} \mathrm{C}$ in sterile sodium phosphate buffer $(10 \mathrm{mM}, \mathrm{pH} 7.2)$ until use.

Bovicin HC5 concentration was determined using a ninhydrin assay (Starcher, 2001). Briefly, bovicin HC5 extract was mixed with equal volume of hydrogen chloride $(12 \mathrm{~N})$ for acid-hydrolysis at $100{ }^{\circ} \mathrm{C}$ for $24 \mathrm{~h}$. Ninhydrin $(1 \mathrm{~g})$ was dissolved in $37.5 \mathrm{ml}$ of ethylene glycol and $12.5 \mathrm{ml}$ of $4 \mathrm{~N}$ sodium acetate buffer ( $\mathrm{pH} 5.5$ ). Stannous chloride solution $(1.25 \mathrm{ml}$ ) freshly prepared by dissolving $50 \mathrm{mg}$ of stannous chloride in $500 \mu \mathrm{l}$ of ethylene glycol was added to the ninhydrin-reagent. The acid-hydrolyzed sample was diluted 100 fold with distilled water. To the tubes containing $200 \mu \mathrm{l}$ of distilled water, $200 \mu \mathrm{l}$ of the diluted

Table 1

Strains used in this study.

\begin{tabular}{lll}
\hline Strain & Origin & Reference \\
\hline $\begin{array}{l}\text { S. bovis } \\
\text { HC5 }\end{array}$ & Isolated from bovine rumen & Mantovani et al. (2001) \\
$\begin{array}{ll}\text { S. aureus } \\
\text { COL }\end{array}$ & Isolated from human, MRSA ${ }^{\mathrm{a}}$ & Shafer and Iandolo (1979) \\
RN 6911 & RN 6390-isogenic agr mutant & Novick et al. (1993) \\
HG 001 & NCTC 8325 derivative, MSSA & Herbert et al. (2010) \\
D4-106.06 & Isolated from bovine mastitis & Poutrel and Lerondelle (1978) \\
\hline
\end{tabular}

\footnotetext{
a MRSA, methicillin-resistant S. aureus.
}

b MSSA, methicillin-sensitive S. aureus. 
samples and $600 \mu \mathrm{l}$ of ninhydrin-reagent were added. After incubation at $100{ }^{\circ} \mathrm{C}$ for $10 \mathrm{~min}$ in the dark, the absorbance was measured at $575 \mathrm{~nm}$. The standard curve was constructed with bovine serum albumin (Sigma-Aldrich, Germany), in a concentration of $0.25-10 \mu \mathrm{g} / \mu \mathrm{l}$ in distilled water.

\subsection{Susceptibility to the bacteriocins and adhesion testing}

In order to determine the Minimal Inhibitory Concentration (MIC) of bovicin HC5 and nisin, $200 \mu \mathrm{l}$ of synthetic medium supplemented with increasing bovicin HC5 and nisin concentrations (from 0.2 to $2.0 \mu \mathrm{M}$ ) was transferred to 96-well microtiter plates and inoculated with $5 \times 10^{5} \mathrm{cfu} / \mathrm{ml}$ of exponentially growing $\mathrm{S}$. aureus cells (optical density at $\left.500 \mathrm{~nm}\left[\mathrm{OD}_{500}\right], 0.5\right)$ previously propagated in the same medium without bacteriocins. The minimal concentration that prevented turbidity of the medium after $18 \mathrm{~h}$ incubation at $37{ }^{\circ} \mathrm{C}$ was designated as the bovicin HC5 and nisin MIC.

To evaluate the effect of bovicin HC5 and nisin on staphylococcal adhesion, assays were carried out using the same experimental design as previously described for MIC experiments. After $18 \mathrm{~h}$ of incubation, the culture supernatant was discarded, and the surface-attached cells were stained with $200 \mu \mathrm{l}$ of $0.1 \%$ (w/v) crystal violet for $30 \mathrm{~min}$. Subsequently, the crystal violet was removed and the plate was washed three times with water. After air drying for $15 \mathrm{~min}$ at $40{ }^{\circ} \mathrm{C}$, the attached cells were determined at $590 \mathrm{~nm}$ with the microtiter plate reader (Biotek, Germany) by addition of $200 \mu \mathrm{l}$ of $95 \%$ (v/v) ethanol.

MIC and adhesion experiments were conducted in three biological replicates and three technical replicates. Data were expressed as the ratio between the absorbance of violet crystal extract (adhered cells) and the optical density of total cells (planktonic cells) (Viana et al., 2009).

\subsection{Contact angle measurement}

\subsubsection{Surface}

Polystyrene coupons (20 mm $\times 10 \mathrm{~mm} \times 1 \mathrm{~mm}$ ) were first cleaned by washing with liquid neutral detergent and water, followed by rinsing with distilled water and then immersing in $70 \%$ ethyl alcohol for $1 \mathrm{~h}$ to remove fat. Subsequently, they were rinsed with distilled water and air dried under UV light. The cleaned and sanitized coupons were preconditioned for $18 \mathrm{~h}$ at $37{ }^{\circ} \mathrm{C}$ by immerging in synthetic medium without bacteriocins or in synthetic medium with $0.4 \mu \mathrm{M}$ of bovicin HC5 or nisin.

The contact angles between the surface and the ultra-pure water, formamide (LGC Bio, Brazil) and $\alpha$-bromonaphthalene (Merck, Germany) were determined using a goniometer (Kruss, Germany). Contact angle measurements of $2.0 \mu \mathrm{l}$ drop were taken each second for $30 \mathrm{~s}$ for all liquids. Experiments were conducted in three biological replicates and three technical replicates.

\subsubsection{Microorganism}

Contact angles of S. aureus COL surface were determined on a layer of vegetative cells (Busscher et al., 1984). First, pre-warmed medium at $37^{\circ} \mathrm{C}$ was inoculated with cells from an overnight culture to an initial $\mathrm{OD}_{500}$ of 0.1 and monitored by measuring the OD until the culture reached an $\mathrm{OD}_{500}$ of 0.5 . At that time, the culture was exposed to $0.4 \mu \mathrm{M}$ of bovicin HC5 or nisin followed by static incubation at $37{ }^{\circ} \mathrm{C}$ for $18 \mathrm{~h}$. Growth in medium without bacteriocins was performed as a control.

Later, the suspension was centrifuged at $4000 \times g$ at $4{ }^{\circ} \mathrm{C}$ for $10 \mathrm{~min}$ and then, washed three times in $0.1 \mathrm{M}$ phosphate-buffered saline (PBS). The pellet was resuspended in the same buffer and then filtered using acetate cellulose membrane $(0.45 \mu \mathrm{m}$ pore size, $47 \mathrm{~mm}$ diameter $)$. During the filtration, $30 \mathrm{ml}$ of ultra-pure water was added.

To standardize the moisture content, the membranes were transferred into Petri dishes containing 1\% (w/v) agar and 10\% (v/v) glycerol.
The membranes were cut to determine the contact angle with the three different polarity liquids.

\subsubsection{Determination of the total interfacial tension $\left(\gamma_{s}^{\text {tot }}\right)$}

The total interfacial tension was determined by the sum of the apolar and polar components of the respective surfaces (Eq. (1)):

$\gamma_{1}^{\text {tot }}(1+\cos \theta)=2 \sqrt{\gamma_{s}^{\mathrm{LW}} \gamma_{1}^{\mathrm{LW}}}+2 \sqrt{\gamma_{s}^{-} \gamma_{1}^{+}}+2 \sqrt{\gamma_{s}^{+} \gamma_{1}^{-}}$

where $\gamma_{1}^{\text {tot }}$ is the total interfacial tension of the liquid; $\gamma^{\mathrm{LW}}$ is the interfacial tension of the interactions of the Lifshitz-van der Waals forces; $\gamma^{+}$ is the interfacial tension of the electron acceptor component of the acidbase component; $\gamma^{-}$is the interfacial tension of the electron donor component of the acid-base component, $\theta$ is the contact angle, and $\mathrm{s}$ and $l$ indicate surface and liquid, respectively (Van Oss and Giese, 1995).

The three components of the interfacial tension of the surfaces were determined from the contact angles obtained from three liquids with different polarities, whose interfacial tensions are known, as shown in Table 2.

The interfacial tension is the result of the sum of the two components ( $\gamma_{\mathrm{s}}^{\mathrm{LW}}$ and $\left.\gamma_{\mathrm{s}}^{\mathrm{AB}}\right)$ :

$\gamma_{\mathrm{s}}^{\mathrm{LW}}=11.1\left(1+\cos \theta_{\mathrm{B}}\right)^{2}$

$\gamma_{s}^{\mathrm{AB}}=2 \sqrt{\gamma_{s}^{+} \gamma_{s}^{-}}$

$\gamma_{s}^{\text {tot }}=\gamma_{s}^{\mathrm{LW}}+\gamma_{\mathrm{s}}^{\mathrm{AB}}$

where $\gamma_{\mathrm{s}}^{\mathrm{LW}}$ is the interfacial tension of the interactions of the Lifshitz-van der Waals forces; $\theta_{\mathrm{B}}$ is the contact angle obtained with $\alpha$-bromonaphthalene; $\gamma_{s}^{\mathrm{AB}}$ is the polar component of the Lewis acidbase interaction; $\gamma_{s}^{+}$is the interfacial tension of the electron acceptor component of the acid-base component; $\gamma_{s}^{-}$is the interfacial tension of the electron donor component of the acid-base component and $\gamma_{s}^{\text {tot }}$ is the total interfacial tension of the surface.

\subsubsection{Free energy of interaction $\left(\Delta G_{\text {sws }}^{T O T}\right)$}

The total free energy of interaction among molecules of the surface (s) immersed in water ( $\mathrm{w}$ ) was determined by the sum of the apolar and polar free energies of interaction, $\Delta G_{\mathrm{sws}}^{\mathrm{LW}}$ and $\Delta G_{\mathrm{sws}}^{\mathrm{AB}}$, respectively.

$\Delta G_{\text {sws }}^{\mathrm{TOT}}=\Delta G_{\text {sws }}^{\mathrm{LW}}+\Delta G_{\text {sws }}^{\mathrm{AB}}$

$\Delta G_{\mathrm{sws}}^{\mathrm{LW}}=-2 \cdot \sqrt{\gamma_{\mathrm{s}}^{\mathrm{LW}}-\gamma_{\mathrm{w}}^{\mathrm{LW}}}$

$\Delta G_{\mathrm{sws}}^{\mathrm{AB}}=-4\left(\sqrt{\gamma_{\mathrm{s}}^{+} \gamma_{\mathrm{s}}^{-}}+\sqrt{\gamma_{\mathrm{w}}^{+} \gamma_{\mathrm{w}}^{-}}-\sqrt{\gamma_{\mathrm{s}}^{+} \gamma_{\mathrm{w}}^{-}}-\sqrt{\gamma_{\mathrm{w}}^{+} \gamma_{\mathrm{s}}^{-}}\right)$

\subsubsection{Determination of the total free energy of adhesion $\left(\Delta G_{\text {adhesion }}\right)$}

Using the values of the components of the interfacial tensions, it is possible to determine the $\Delta G_{\text {adhesion }}$ between two surfaces (microbial

Table 2

Components of the interfacial tensions of the substances at $25{ }^{\circ} \mathrm{C}$.

\begin{tabular}{llllr}
\hline \multirow{2}{*}{ Substances } & \multicolumn{4}{l}{ Interfacial tension $\left(\mathrm{mJ} / \mathrm{m}^{2}\right)$} \\
\cline { 2 - 5 } & $\gamma_{1}^{\text {tot }}$ & $\gamma_{1}^{\mathrm{LW}}$ & $\gamma_{1}^{+}$ & $\gamma_{1}^{-}$ \\
\hline$\alpha$-Bromonaphthalene & 44.4 & 44.4 & 0.0 & 0.0 \\
Water & 72.8 & 21.8 & 25.5 & 25.5 \\
Formamide & 58.0 & 39.0 & 2.28 & 39.6 \\
\hline
\end{tabular}


cells (b) and polystyrene surface (s)):

$\gamma_{\mathrm{bs}}=\gamma_{\mathrm{bs}}^{\mathrm{LW}}+\gamma_{\mathrm{bs}}^{\mathrm{AB}}$

$\gamma_{\mathrm{bs}}^{\mathrm{LW}}=\gamma_{\mathrm{b}}^{\mathrm{LW}}+\gamma_{\mathrm{s}}^{\mathrm{LW}}-2 \sqrt{\gamma_{\mathrm{b}}^{\mathrm{LW}} \gamma_{\mathrm{s}}^{\mathrm{LW}}}$

$\gamma_{\mathrm{bs}}^{\mathrm{AB}}=2\left(\sqrt{\gamma_{\mathrm{b}}^{+} \gamma_{\mathrm{b}}^{-}}+\sqrt{\gamma_{\mathrm{s}}^{+}} \gamma_{\mathrm{s}}^{-}-\sqrt{\gamma_{\mathrm{b}}^{+} \gamma_{\mathrm{s}}^{-}}-\sqrt{\gamma_{\mathrm{b}}^{-}} \gamma_{\mathrm{s}}^{+}\right)$

When free energy is related to the interfacial tension, $\Delta G_{\text {adhesion }}$ can then be represented by the following:

$\Delta G_{\mathrm{adhesion}}=\Delta G_{\mathrm{bls}}^{\mathrm{LW}}+\Delta G_{\mathrm{bls}}^{\mathrm{AB}}$

$\Delta G_{\mathrm{bls}}^{\mathrm{LW}}+\gamma_{\mathrm{bs}}^{\mathrm{LW}}-\gamma_{\mathrm{bl}}^{\mathrm{LW}}-\gamma_{\mathrm{sl}}^{\mathrm{LW}}$

$\Delta G_{\mathrm{bls}}^{\mathrm{AB}}=\gamma_{\mathrm{bs}}^{\mathrm{AB}}-\gamma_{\mathrm{bl}}^{\mathrm{AB}}-\gamma_{\mathrm{sl}}^{\mathrm{AB}}$

where $\gamma_{b s}$ is the interfacial tension between the bacterial surfaces and the adhesion surface; $\gamma_{\mathrm{bl}}$ is the interfacial tension between the bacterial surfaces and the liquid; and $\gamma_{\mathrm{sl}}$ is the interfacial tension between the adhesion surfaces and the liquid.

The $\Delta G_{\text {adhesion }}$ values allow for the evaluation of the thermodynamics of the adhesion process: if $\Delta G_{\text {adhesion }}<0$, the process is favorable; if $\Delta G_{\text {adhesion }}>0$, the process is unfavorable.

\subsection{Impact of bovicin HC5 and nisin on biofilm-related gene expression} in S. aureus

\subsubsection{Sample preparation and total RNA extraction}

Expression of the genes $i c a D$, fnbA, and $c l f B$, related to adhesion and biofilm formation, and rnaIII, gene involved in the quorum sensing mechanism was evaluated after exponentially growing cells of S. aureus $\mathrm{COL}\left(\mathrm{OD}_{500} 0.5\right)$ have been exposed to $0.4 \mu \mathrm{M}$ bovicin HC5 or nisin in synthetic medium for $18 \mathrm{~h}$, statically at $37^{\circ} \mathrm{C}$. Untreated cells were also evaluated after $18 \mathrm{~h}$ of growth in synthetic medium.

Bacterial cells were collected by centrifugation for $5 \mathrm{~min}$ at $6000 \times \mathrm{g}$. Total RNA was obtained by phenol-chloroform extraction (TRIzol ${ }^{\circledR}$, Invitrogen, USA) according to the manufacturer's instructions after a 40 min pre-treatment of the cells with $0.8 \mu \mathrm{g} / \mu \mathrm{l}$ of lysozyme and $2.0 \times 10^{-5} \mathrm{U} / \mu \mathrm{l}$ of lysostaphin in $300 \mu \mathrm{l}$ of TE buffer. Purified RNA was eluted in $30 \mu \mathrm{l}$ of Ultrapure ${ }^{\mathrm{TM}}$ RNase/DNase-free distilled water (Invitrogen, USA) and stored at $-20^{\circ} \mathrm{C}$. The concentration and purity of the RNA were evaluated by spectrometry at $260 \mathrm{~nm}$ and $280 \mathrm{~nm}$. The integrity of the RNA was confirmed by $1 \%(\mathrm{w} / \mathrm{v})$ agarose gel electrophoresis.

\subsection{2. cDNA synthesis and $R T-q P C R$}

Aliquots of $2 \mu \mathrm{g}$ of total RNA were treated with RQ1 RNase-free DNase (Promega, USA) for DNA elimination according to the manufacturer's instructions. cDNA synthesis was performed using Improm-II Reverse Transcription System kit (Promega, USA) following the manufacturer's recommendations. The mixture was incubated at $25{ }^{\circ} \mathrm{C}$ for $5 \mathrm{~min}, 42{ }^{\circ} \mathrm{C}$ for $2 \mathrm{~h}$ and $70{ }^{\circ} \mathrm{C}$ for $15 \mathrm{~min}$.

The relative mRNA levels of biofilm-related genes were analyzed by quantitative real-time polymerase chain reaction (RT-qPCR) using SYBR $®$ Green PCR-Master Mix (Applied Biosystems, USA) in $25 \mu \mathrm{l}$ reaction volumes containing $1 \mu \mathrm{l}$ of cDNA template, $1 \mu \mathrm{l}$ of each primer at $0.5 \mu \mathrm{M}$ (Table 3), $12.5 \mu \mathrm{l}$ of SYBR ${ }^{\circ}$ Green PCR-Master Mix and $9.5 \mu \mathrm{l}$ of Ultrapure $^{\mathrm{TM}} \mathrm{RNase} / \mathrm{DNase}$-free distilled water and the following conditions: $50{ }^{\circ} \mathrm{C}$ for $2 \mathrm{~min}, 95^{\circ} \mathrm{C}$ for $10 \mathrm{~min}, 40$ cycles of $95{ }^{\circ} \mathrm{C}$ for $15 \mathrm{~s}$ and
Table 3

Sequences of primers used for RT-qPCR.

\begin{tabular}{lll}
\hline Gene & Nucleotide sequence of primers $\left(5^{\prime}-3^{\prime}\right)$ & Reference \\
\hline icaD & 1-GGGTGGATCCTTAGTGTTACAATTTT & Korem et al. (2010) \\
& 2-TGACTTTTGGTAATTCAAGGTTGTC & \\
fnbA & 1-CGACACAACCTCAAGACAATAGCGG & Ster et al. (2005) \\
& 2-CGTGGCTTACTTTCTGATGCCGTC & \\
clfB & 1-AATGCCATCATTGCACCAAA & Korem et al. (2010) \\
& 2-CACAAAACTGATGCTTTACCAGAAA & \\
rnalII & 1-AGTCACCGATTGTGAAATGATATCT & Pang et al. (2010) \\
\multirow{2}{*}{ gyrB } & 2-AGGAAGGAGTGATTCAATGGC & Korem et al. (2010) \\
& 1-ATCGGTGGCGACTTTGATCTA & \\
\hline
\end{tabular}

$60{ }^{\circ} \mathrm{C}$ for $1 \mathrm{~min}$. Abundance of each specific mRNA was calculated relatively to the expression of the housekeeping gene DNA gyrase, B subunit (gyrB) based on $2^{-\Delta \Delta C t}$ method (Livak and Schmittgen, 2001). The amplifications were performed in 96-well PCR plates using CFX96 Touch $^{\text {TM }}$ Real-Time PCR Detection System (Bio-Rad, USA). The fluorescence data for each sample were converted to cycle threshold $(\mathrm{Ct})$ values using the software Bio-Rad CFX Manager 2.0. Experiments were conducted in three biological replicates and three technical replicates. Statistical differences were examined using one-way ANOVA followed by Tukey's test. A $p$-value less than 0.05 was considered to be statistically significant.

\section{Results}

\subsection{Inhibition of S. aureus by bovicin HC5 and nisin}

The MICs of the bacteriocins bovicin HC5 and nisin on four different strains of $S$. aureus were investigated in synthetic medium and the results are shown in Table 4. The MIC value average for bovicin HC5 and nisin was $1.05 \mu \mathrm{M} \pm 0.90$ and $0.90 \mu \mathrm{M} \pm 0.26$, respectively.

Subinhibitory dosages of bovicin HC5 and nisin were tested for their capacity to inhibit adhesion of $S$. aureus in polystyrene 96-well microtiter plates after $18 \mathrm{~h}$ of incubation using the crystal violet method. Adhesion was estimated by calculating the ratio between the absorbance of violet crystal extract and the optical density of total cells. The presence of the bacteriocins in synthetic medium clearly reduced adhesion of the strains COL and RN 6911 to the polystyrene surface (Fig. 1), and the effect of bovicin HC5 and nisin seemed to be similar for that of COL strain. While only bovicin HC5 was able to reduce adhesion of S. aureus HG 001, only nisin at the highest concentration evaluated reduced adhesion of S. aureus D4-106.06 to polystyrene.

\subsection{Contact angle and total free energy of interaction $\left(\Delta G_{s w s}^{T O T}\right)$}

As we observed that subinhibitory dosages of bovicin HC5 and nisin were more effective in adhesion reduction than growth reduction, COL strain was selected to investigate if the presence of bovicin HC5 and nisin in low concentrations could change the hydrophobicity of the bacterial surface and also the polystyrene surface and thus, interfere with the adhesion process.

Table 4

Minimal Inhibitory Concentration of bovicin HC5 and nisin on S. aureus strains.

\begin{tabular}{lll}
\hline \multirow{2}{*}{ S. aureus strains } & MIC of bacteriocins $(\mu \mathrm{M})$ & \\
\cline { 2 - 3 } & Bovicin HC5 & Nisin \\
\hline COL & 1.2 & 1.0 \\
RN 6911 & 1.2 & 1.2 \\
HG 001 & 0.8 & 0.6 \\
D4-106.06 & 1.0 & 0.8
\end{tabular}



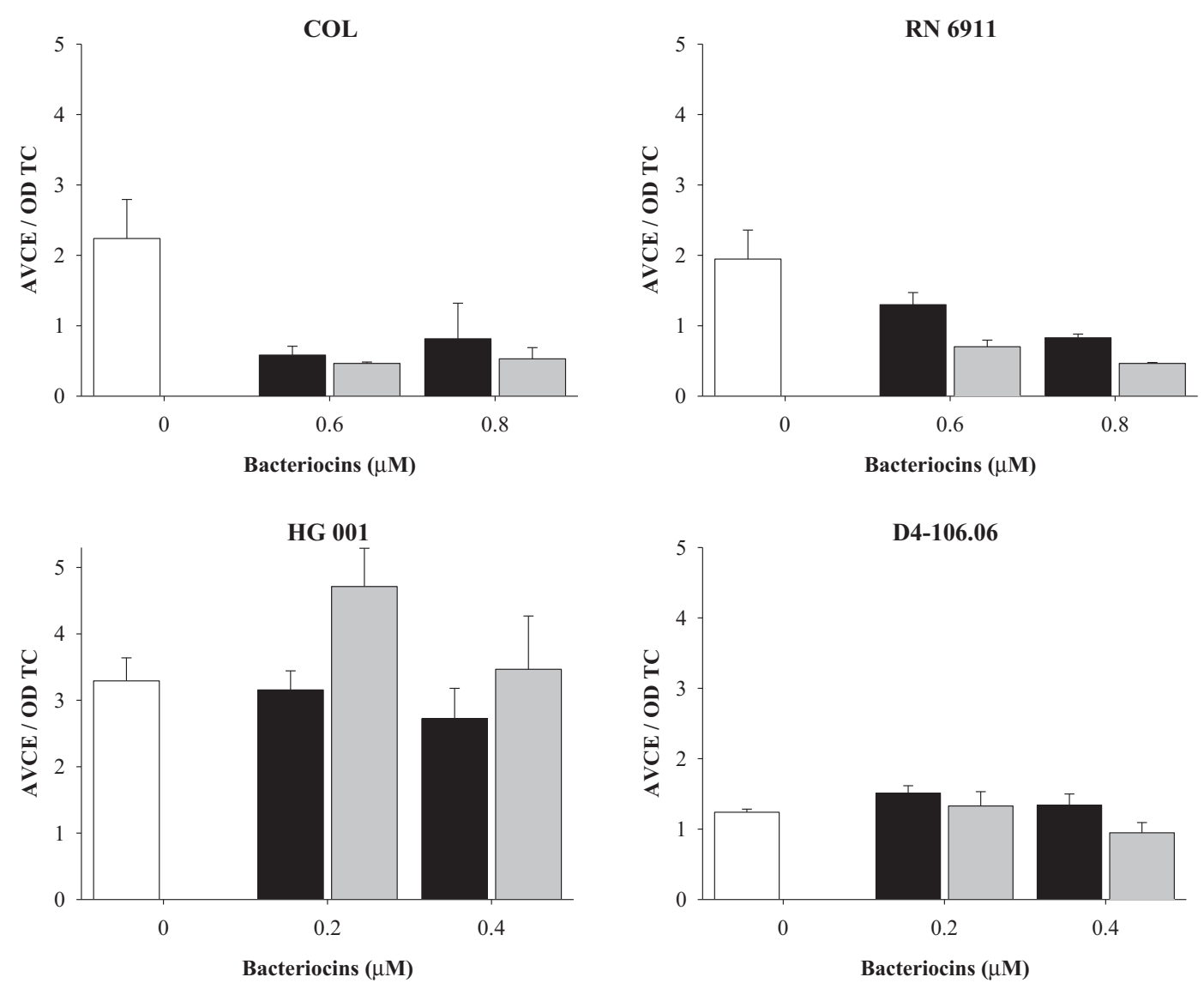

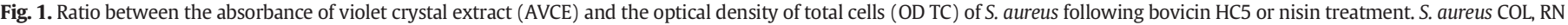

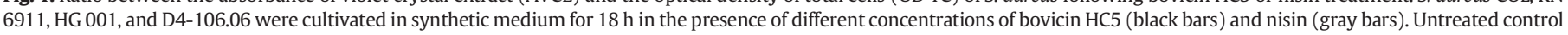
(white bars) is shown.

The measurement of the water contact angle $\left(\Theta_{\mathrm{w}}\right)$ with the polystyrene surface exposed for $18 \mathrm{~h}$ to synthetic medium without bacteriocins was greater than $65^{\circ}$, indicating a hydrophobic profile according to the classification system proposed by Vogler (1998). The presence of the bacteriocins in the synthetic medium drastically changed the hydrophobicity of the polystyrene surface, since $\Theta_{\mathrm{W}}$ with the surface was much lower than $65^{\circ}$ (Table 5). S. aureus COL cellular surface, hydrophilic in the absence of bacteriocins, remained hydrophilic with a small decrease in the contact angle when bacteria grew in the presence of $0.4 \mu \mathrm{M}$ of bovicin HC5 or nisin.

The $\Delta G_{\text {sws }}^{\text {TOT }}$ values are considered a quantitative criterion for hydrophobicity evaluation. According to the calculations, the polystyrene surface treated with synthetic medium without bacteriocins was classified as hydrophobic $\left(\Delta G_{\text {sws }}^{\mathrm{TOT}}<0\right)$ (Table 5$)$. The presence of bovicin HC5 and nisin decreased the hydrophobicity of the polystyrene surface. The bacterial surface, which is hydrophilic, remained hydrophilic $\left(\Delta G_{\text {sws }}^{\mathrm{TOT}}>0\right)$ even after $18 \mathrm{~h}$ of exposure to the bacteriocins (Table 5 ).

\subsubsection{Free energy adhesion ( $\left.\Delta G_{\text {adhesion }}\right)$}

According to thermodynamic theory, adhesion is considered favorable only if the process results in a decrease in total free energy. Thus, the adhesion process was thermodynamically favorable $\left(\Delta G_{\text {adhesion }}=\right.$ $-9.58 \mathrm{~mJ} / \mathrm{m}^{2}$ ) only when the synthetic medium in contact with the polystyrene surface contained no bacteriocins. The free energy of adhesion in the presence of bovicin HC5 and nisin was $23.30 \mathrm{~mJ} / \mathrm{m}^{2}$ and $24.06 \mathrm{~mJ} / \mathrm{m}^{2}$, respectively, with the adhesion process considered thermodynamically unfavorable, confirming the previous results that both bacteriocins decreased the adhesion of S. aureus COL.

Table 5

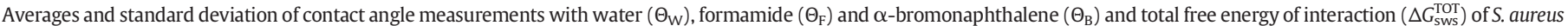
COL and the polystyrene surface (PS) treated with bovicin HC5 and nisin.

\begin{tabular}{|c|c|c|c|c|}
\hline \multirow[t]{2}{*}{ Surface/bacteria } & \multicolumn{3}{|c|}{ Contact angles $\left({ }^{\circ}\right)^{\mathrm{a}}$} & \multirow{2}{*}{$\begin{array}{l}\Delta G_{\mathrm{sws}}^{\mathrm{TOT}} \\
\left(\mathrm{mJ} / \mathrm{m}^{2}\right)\end{array}$} \\
\hline & $\Theta_{\mathrm{W}}$ & $\Theta_{\mathrm{F}}$ & $\Theta_{\mathrm{B}}$ & \\
\hline PS + synthetic medium & $82.4 \pm 4.4$ & $66.2 \pm 5.5$ & $22.9 \pm 1.4$ & -63.7 \\
\hline PS + synthetic medium $+0.4 \mu \mathrm{M}$ bovicin $\mathrm{HC} 5$ & $33.4 \pm 7.9$ & $30.2 \pm 2.9$ & $32.7 \pm 4.8$ & 22.4 \\
\hline $\mathrm{PS}+$ synthetic medium $+0.4 \mu \mathrm{M}$ nisin & $40.5 \pm 1.3$ & $37.0 \pm 0.8$ & $40.9 \pm 2.7$ & 18.1 \\
\hline S. aureus + synthetic medium & $25.3 \pm 2.9$ & $17.7 \pm 0.3$ & $45.0 \pm 1.5$ & 20.3 \\
\hline S. aureus + synthetic medium $+0.4 \mu \mathrm{M}$ bovicin HC5 & $21.9 \pm 3.1$ & $16.6 \pm 0.7$ & $45.9 \pm 1.9$ & 22.8 \\
\hline S. aureus + synthetic medium $+0.4 \mu \mathrm{M}$ nisin & $23.5 \pm 1.1$ & $25.3 \pm 3.8$ & $45.8 \pm 2.3$ & 28.4 \\
\hline
\end{tabular}

\footnotetext{
a Average of three repetitions.
} 


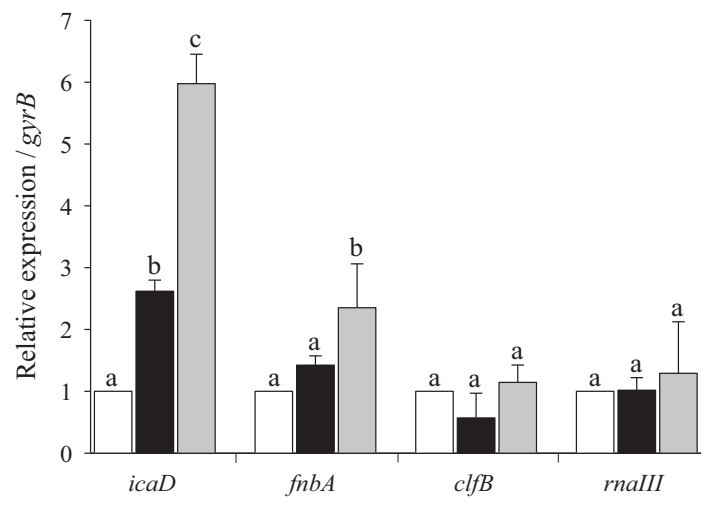

Fig. 2. Comparison of the expression profiles of selected biofilm formation-related genes (icaD, fnbA and $c l f B$ ) and quorum sensing-related gene (rnaIII) in S. aureus COL. Cells were grown in synthetic medium and total RNA was extracted from the cells after $18 \mathrm{~h}$ of exposure to $0.4 \mu \mathrm{M}$ of bovicin HC5 (black bars) and nisin (gray bars) and the expression profile was analyzed by RT-qPCR. Untreated control (white bars) is shown. Means with different letters are significantly different $(p<0.05)$.

\subsection{Effect of bovicin HC5 and nisin on the expression of biofilm-related genes in S. aureus}

The effect of both bacteriocins on the expression of selected genes related to adhesion and biofilm formation (icaD, fnbA and $c l f B$ ) and also on the rnaIII, involved in the quorum sensing mechanism, was investigated.

Low concentrations of bovicin HC5 and nisin increased significantly $(p<0.05)$ the expression of icaD, one of the most studied genes related to biofilm formation by staphylococci, by 2.62 and 5.97 fold, respectively, when compared to the control without bacteriocins (Fig. 2). Nisin interfered more than bovicin HC5 on icaD expression. A more pronounced effect of nisin was also observed in the fibronectin A gene expression, since only this bacteriocin increased significantly $(p<0.05)$ the expression of fnbA by 2.35 fold. The exposure of S. aureus COL for $18 \mathrm{~h}$ to $0.4 \mu \mathrm{M}$ of bovicin HC5 or nisin did not cause significant $(p>0.05)$ changes in the transcription profile of $c l f B$, clumping factor $B$, and rnallI, main effector of agr quorum sensing system in S. aureus (Fig. 2).

\section{Discussion}

For a long time, S. aureus has caused problems in health care. In order to control $S$. aureus growth and biofilm formation various natural substances have been tested. In this work, bovicin HC5 and nisin were tested against different strains of S. aureus aiming to determine MIC and also the effects of subinhibitory concentrations on cell adhesion to the polystyrene surface. Bovicin HC5 and nisin were effective against all strains of $S$. aureus tested in synthetic medium and a similar inhibitory effect was observed for both bacteriocins. The minimum concentrations of bovicin HC5 and nisin able to inhibit the growth of all tested strains were 1.4 and $1.2 \mu \mathrm{M}$, respectively. The lantibiotics bovicin HC5 and nisin share a similar mode of action using lipid II, an essential precursor in the biosynthesis of cell wall, as docking molecule and forming pores at sensitive membranes leading to cell death due to loss of intracellular compounds (Paiva et al., 2011).

Recently, our group reported that the bacteriocins bovicin HC5 and nisin were effective to inhibit $S$. aureus growth in milk (Pimentel-Filho et al., 2013) and in fresh cheese (Pimentel-Filho et al., 2014). These results reinforce the idea that not only nisin, already authorized as a food additive in many countries, but also bovicin HC5 has potential application as a natural food preservative. Other bacteriocins such as enterocin AS-48 (Ananou et al., 2010; Ananou et al., 2004), epidermicin NI01 (Sandiford and Upton, 2012), lacticin Q (Okuda et al., 2013), and plantaricin ZJ008 (Zhu et al., 2014) have been tested and were effective against $S$. aureus, even those called drug or multidrug-resistant.

Development of technologies to control microbial adhesion and biofilm formation is desired for food industries. Our study revealed that subinhibitory dosages of bovicin $\mathrm{HC} 5$ and nisin reduced the adhesion of the pathogen to the polystyrene frequently used in trays, utensils and food packing. Low dosages of nisin as $7.5 \mu \mathrm{M}$ ( $25 \mathrm{IU} / \mathrm{ml}$ ) were able to reduce staphylococcal biofilms on polypropylene coupons and were even more effective against planktonic cell of $S$. aureus (Cabo et al. 2009). Bacteriocin-like substances produced by lactobacilli suppressed biofilm formation on the polystyrene surface by $S$. aureus and S. epidermidis and induced ultrastructural changes leading to their destruction (Sadowska et al., 2010). Davison et al. (2010) verified that nisin accessed the interior of biofilm cell clusters of S. epidermidis on glass faster than other antimicrobial agents as chlorine and glutaraldehyde resulting in a rapid and uniform loss of green fluorescence, indicating at least changes in the membrane permeabilization, without any removal of biofilm. All these results reinforce the idea that bacteriocins can be a potential strategy to prevent adhesion and to control biofilm formation.

Generally, any surface is vulnerable to biofilm development including plastic, glass, metal, wood, and food products but the surface physiochemical properties play an important role in bacterial adhesion (Ferreira et al., 2010). By water contact angle values, a qualitative criterion, we observed that the cell surface of S. aureus COL growing in synthetic medium with or without bovicin HC5 and nisin was hydrophilic. Our result was in agreement with reports which found that the S. aureus surface is hydrophilic (Hamadi et al., 2005; Kouidhi et al., 2010). The polystyrene surface conditioned for $18 \mathrm{~h}$ with synthetic medium was hydrophobic which is considered favorable for bacterial adhesion. Evaluating the hydrophobicity of the polystyrene surface, Biazar et al. (2011) found a contact angle of $90.1^{\circ}$ confirming its hydrophobic character. However, after $18 \mathrm{~h}$ of conditioning with synthetic medium added to bovicin HC5 or nisin, the polystyrene surface became hydrophilic $\left(\Theta_{\mathrm{W}}<65^{\circ}\right)$. Our data showed that the decrease in the hydrophobicity on treated surfaces indicates one of the reasons for bacterial attachment decrease. Hydrophobicity is an important propriety and represents the wettability of a surface and, in aqueous medium, adhesion is favored between hydrophobic surfaces, which can enter in closer contact by squeezing the water layer between them (Teixeira et al., 2005). After conditioning with surfactant, the polystyrene surface became more hydrophilic (Zeraik and Nitschke, 2010). It has been shown, that Salmonella and Listeria preferably adhere in a higher number to hydrophobic surfaces than the hydrophilic ones (Donlan and Costerton, 2002; Sinde and Carballo, 2000).

In order to predict the ability of the pathogen to adhere to those treated or untreated polystyrene surfaces, and further to form biofilms, the free energy of interaction between the micro-organisms and the surface, when immersed in the same synthetic medium condition with or without bacteriocin, was calculated. Only in the medium without bacteriocins the adhesion process was thermodynamically favorable. Since the total free energy of adhesion was positive, in the medium containing bacteriocins, the adhesion process was considered unfavorable. Teixeira et al. (2005) also demonstrated that adhesion of some isolates of Pseudomonas aeruginosa and Staphylococcus sciuri was thermodynamically favorable to stainless steel and rubber, which were considered hydrophobic and unfavorable to glass and polymethylacrylate surfaces, classified as hydrophilic.

Although many studies have been performed aiming on a better understanding of biofilm formation by S. aureus, the knowledge on the effect of bacteriocins on gene expression is still limited. Our work investigated exposure to bovicin $\mathrm{HC} 5$ and nisin was also related to an altered expression of four selected genes involved in biofilm formation by S. aureus COL. Interestingly, we found icaD over-expressed in the presence of both bovicin HC5 and nisin. In staphylococci, production of polysaccharide intercellular adhesin (PIA) by the enzyme products of the 
icaADBC operon is the best understood mechanism of biofilm development, making the ica genes a potential target for biofilm inhibitors (Oduwole et al., 2010). A similar effect was observed by Nuryastuti et al. (2009) when evaluating subinhibitory concentrations of cinnamon oil on the expression of icaA in S. epidermidis, another important gene of icaADBC operon evaluated in studies involving biofilm formation by staphylococcal species. They found that even reducing biofilm formation on the polystyrene surface, $0.01 \%$ of cinnamon oil enhanced icaA expression (Nuryastuti et al., 2009). On the other hand, low dosages of povidone-iodine, a complex of polyvinyl pyrrilidine and triiodine ions widely used as an antiseptic in trauma and orthopedic surgery, decreased icaA expression and, thus, the biofilm forming capacity of S. aureus RN4220 (Oduwole et al., 2010). According to the reports in the literature, the expression of the ica genes is highly variable and can be induced by variations in the culture conditions, such as an increase in the concentration of sugars or other substances that induce stress (Cho et al., 2002; Oliveira and de Lourdes Cunha, 2010).

While both bacteriocins did not interfere in the expression of $\operatorname{clf} B$, only nisin was able to up-regulate $f n b A$. Differences in the expression of $f n b A$ and $c l f B$ in the presence of antimicrobial agents were also reported. Rasigade et al. (2011) reported that although subinhibitory concentration of rifampicin reduced bacterial adhesion to human fibronectin, the antibiotic did not affect $f n b A / B$ transcription by five $S$. aureus strains. However, low dosages of oxacillin, moxifloxacin and linezolid led to the development of a hyper-adhesive phenotype in the fibronectin adhesion assay, increasing also $\mathrm{fnbA} / \mathrm{B}$ expression (Rasigade et al., 2011). Sublethal dosages of tigecycline were investigated on biofilm formation by 16 methicillin-resistant $S$. aureus isolates and the transcriptome analysis revealed that the antibiotic was able to reduce expression of $i c a C$, otherwise upregulation of $f n b A$ and $c l f B$, which encode adhesins which attach to human proteins, was observed (Smith et al., 2010).

Biofilm formation can be induced by conditions that are potentially toxic for bacterial cells, such as high levels of osmolarity, detergents, urea, ethanol, oxidative stress, and the presence of sub-MICs of some antibiotics (Nuryastuti et al., 2009).

No difference in rnalII expression was observed in the presence of bovicin HC5 or nisin. The agr system effector, rnalII, regulates the expression of a large number of target genes, including downregulating biofilm-related genes as $f n b A$ and $c l f B$ (Xue et al., 2012); it was expected that the bacteriocins would enhance the rnaIII transcription and consequently reduce the expression of fnbA and clfB.

To our knowledge, this is the first study reporting that bacteriocins change the hydrophobicity of polystyrene surfaces. Even expressing $i c a D$ and fnbA in the presence of the bacteriocins, the adhesion of $S$. aureus was reduced since the free energy of adhesion was not favorable, indicating a difficulty for the bacteria to get in close contact with the surface. This is a very interesting finding since to prevent microbial adhesion to food contact surfaces is much more effective than to remove biofilms already established. Thus, bovicin HC5 and nisin appear as a potential alternative to inhibit the initial step of biofilm formation.

\section{Acknowledgments}

N.J.P.F. was supported by a fellowship (8974/11-0) from Coordenação de Aperfeiçoamento de Pessoal de Nível Superior (CAPES, Brasília, Brazil).

We thank Kathrin Riedel and Stephan Fuchs, from University of Greifswald, for important suggestions and detailed criticism of the manuscript.

\section{References}

Ananou, S., Valdivia, E., Marínez Bueno, M., Gálvez, A., Maqueda, M., 2004. Effect of combined physico-chemical preservatives on enterocin AS-48 activity against the enterotoxigenic Staphylococcus aureus CECT 976 strain. J. Appl. Microbiol. 97, 48-56.
Ananou, S.,Baños, A.,Maqueda, M.,Martínez-Bueno, M.,Gálvez, A.,Valdivia, E., 2010. Effect of combined physico-chemical treatments based on enterocin AS-48 on the control of Listeria monocytogenes and Staphylococcus aureus in a model cooked ham. Food Control 21, 478-486.

Antolinos, V., Munoz, M., Ros-Chumillas, M., Aznar, A., Periago, P.M., Fernandez, P.S., 2011. Combined effect of lysozyme and nisin at different incubation temperature and mild heat treatment on the probability of time to growth of Bacillus cereus. Food Microbiol. 28, 305-310.

Araújo, E.A., Bernardes, P.C., Andrade, N.J., Fernandes, P.E., Sá, J.P.N., 2009. Gibbs free energy of adhesion of Bacillus cereus isolated from dairy plants on different food processing surfaces evaluated by the hydrophobicity. Int. J. Food Sci. Technol. 44, 2519-2525.

Arciola, C.R., Campoccia, D., Baldassarri, L., Donati, M.E., Pirini, V., Gamberini, S., Montanaro, L., 2006. Detection of biofilm formation in Staphylococcus epidermidis from implant infections. Comparison of a PCR-method that recognizes the presence of ica genes with two classic phenotypic methods. J. Biomed. Mater. Res. Part A 76, 425-430.

Argudín, M.Á., Mendoza, M.C., Rodicio, M.R., 2010. Food poisoning and Staphylococcus aureus enterotoxins. Toxins 2,1751-1773.

Atshan, S.S.,Shamsudin, M.N., Karunanidhi, A., Belkum, A.v., Lung, L.T.T.,Sekawi, Z., Nathan, J.J., Ling, K.H.,Seng, J.S.C.,Ali, A.M., 2013. Quantitative PCR analysis of genes expressed during biofilm development of methicillin resistant Staphylococcus aureus (MRSA). Infect. Genet. Evol. 18, 106-112.

Biazar, E., Heidari, M., Asefnezhad, A., Montazeri, N., 2011. The relationship between cellular adhesion and surface roughness in polystyrene modified by microwave plasma radiation. Int. J. Nanomedicine 6, 631-639.

Bryers, J.D., Ratner, B.D., 2004. Bioinspired implant materials befuddle bacteria. ASM News-Am. Soc. Microbiol. 70, 232-237.

Busscher, H.J., Weerkamp, A.H., Van der Mei, H.C., Van Pelt, A.W., De Jong, H.P., Arends, J., 1984. Measurement of the surface free energy of bacterial cell surfaces and its relevance for adhesion. Appl. Environ. Microbiol. 48, 980-983.

Busscher, H.J., Norde, W.,Sharma, P.K.,Van der Mei, H.C., 2010. Interfacial re-arrangement in initial microbial adhesion to surfaces. Curr. Opin. Colloid Interface Sci. 15, 510-517.

Caballero Goméz, N.,Abriouel, H.,Grande, M.J.,Pérez Pulido, R., Gálvez, A., 2013. Combined treatments of enterocin AS-48 with biocides to improve the inactivation of methicillin-sensitive and methicillin-resistant Staphylococcus aureus planktonic and sessile cells. Int. J. Food Microbiol. 163, 96-100.

Cabo, M.L., Herrera, J.J., Crespo, M.D., Pastoriza, L., 2009. Comparison among the effectiveness of ozone, nisin and benzalkonium chloride for the elimination of planktonic cells and biofilms of Staphylococcus aureus CECT4459 on polypropylene. Food Control 20, 521-525.

Cho, S.-H., Naber, K., Hacker, J.,Ziebuhr, W., 2002. Detection of the icaADBC gene cluster and biofilm formation in Staphylococcus epidermidis isolates from catheter-related urinary tract infections. Int. J. Antimicrob. Agents 19, 570-575.

Chung, E., Yiacoumi, S., Tsouris, C., 2014. Interaction forces between spores and planar surfaces in aqueous solutions. Colloids Surf. A Physicochem. Eng. Asp. 443, 80-87.

Davison, W.M.,Pitts, B.,Stewart, P.S., 2010. Spatial and temporal patterns of biocide action against Staphylococcus epidermidis biofilms. Antimicrob. Agents Chemother. 54, 2920-2927.

Donlan, R.M., Costerton, J.W., 2002. Biofilms: survival mechanisms of clinically relevant microorganisms. Clin. Microbiol. Rev. 15, 167-193.

Fagundes, P.C., Ceotto, H., Potter, A., de Paiva, Vasconcelos, Brito, M.A., Brede, D., Nes, I.F., Bastos, M.d.C.d.F., 2011. Hyicin 3682, a bioactive peptide produced by Staphylococcus hyicus 3682 with potential applications for food preservation. Res. Microbiol. 162, 1052-1059.

Ferreira, C., Pereira, A.M., Melo, L.F., Simões, M., 2010. Advances in industrial biofilm control with micro-nanotechnology. Current Research, Technology and Education Topics in Applied Microbiology and Microbial Biotechnology. 2, pp. 845-854.

Gerke, C., Kraft, A., Süßmuth, R., Schweitzer, O., Götz, F., 1998. Characterization of the $\mathrm{N}$-acetylglucosaminyltransferase activity involved in the biosynthesis of the Staphylococcus epidermidis polysaccharide intercellular adhesin. J. Biol. Chem. 273, 18586-18593.

Gertz, S., Engelmann, S., Schmid, R., Ohlsen, K., Hacker, J., Hecker, M., 1999. Regulation of sigma B-dependent transcription of sigB and asp23 in two different Staphylococcus aureus strains. Mol. Gen. Genet. 261, 558-566.

Hamadi, F., Latrache, H., Mabrrouki, M., Elghmari, A., Outzourhit, A., Ellouali, M., Chtaini, A., 2005. Effect of $\mathrm{pH}$ on distribution and adhesion of Staphylococcus aureus to glass. J. Adhes. Sci. Technol. 19, 73-85.

Herbert, S.,Ziebandt, A.K.,Ohlsen, K.,Schafer, T.,Hecker, M.,Albrecht, D.,Novick, R.,Gotz, F., 2010. Repair of global regulators in Staphylococcus aureus 8325 and comparative analysis with other clinical isolates. Infect. Immun. 78, 2877-2889.

Herrera, J.J.R., Cabo, M.L., Gonzalez, A., Pazos, I., Pastoriza, L., 2007. Adhesion and detachment kinetics of several strains of Staphylococcus aureus subsp. aureus under three different experimental conditions. Food Microbiol. 24, 585-591.

Hori, K., Matsumoto, S., 2010. Bacterial adhesion: from mechanism to control. Biochem. Eng. J. 48, 424-434.

Korem, M., Gov, Y., Rosenberg, M., 2010. Global gene expression in Staphylococcus aureus following exposure to alcohol. Microb. Pathog. 48, 74-84.

Kouidhi, B.,Zmantar, T., Hentati, H., Bakhrouf, A., 2010. Cell surface hydrophobicity, biofilm formation, adhesives properties and molecular detection of adhesins genes in Staphylococcus aureus associated to dental caries. Microb. Pathog. 49, $14-22$.

Le Loir, Y., Baron, F., Gautier, M., 2003. Staphylococcus aureus and food poisoning. Genet. Mol. Res. 2, 63-76.

Livak, K.J.,Schmittgen, T.D., 2001. Analysis of relative gene expression data using real-time quantitative PCR and the $2^{-\Delta \Delta \mathrm{CT}}$ method. Methods $25,402-408$. 
Mahalik, N.P., Nambiar, A.N., 2010. Trends in food packaging and manufacturing systems and technology. Trends Food Sci. Technol. 21, 117-128.

Mantovani, H.C., Russell, J.B., 2003. Inhibition of Listeria monocytogenes by bovicin HC5, a bacteriocin produced by Streptococcus bovis HC5. Int. J. Food Microbiol. 89, 77-83.

Mantovani, H.C., Kam, D.K., Ha, J.K., Russell, J.B., 2001. The antibacterial activity and sensitivity of Streptococcus bovis strains isolated from the rumen of cattle. FEMS Microbiol. Ecol. 37, 223-229.

Mantovani, H.C., Hu, H., Worobo, R.W., Russell, J.B., 2002. Bovicin HC5, a bacteriocin from Streptococcus bovis HC5. Microbiology 148, 3347-3352.

Nostro, A., Scaffaro, R., Ginestra, G., D'Arrigo, M., Botta, L., Marino, A., Bisignano, G., 2010. Control of biofilm formation by poly-ethylene-co-vinyl acetate films incorporating nisin. Appl. Microbiol. Biotechnol. 87, 729-737.

Novick, R.P., Geisinger, E., 2008. Quorum sensing in staphylococci. Annu. Rev. Genet. 42, 541-564.

Novick, R.P., Ross, H.F., Projan, S.J., Kornblum, J., Kreiswirth, B., Moghazeh, S., 1993. Synthesis of staphylococcal virulence factors is controlled by a regulatory RNA molecule. EMBO J. 12, 3967-3975.

Nuryastuti, T.,van der Mei, H.C.,Busscher, H.J.,Iravati, S.,Aman, A.T.,Krom, B.P., 2009. Effect of cinnamon oil on icaA expression and biofilm formation by Staphylococcus epidermidis. Appl. Environ. Microbiol. 75, 6850-6855.

Oduwole, K.O.,Glynn, A.A.,Molony, D.C.,Murray, D., Rowe, S.,Holland, L.M.,McCormack, D.J. O'Gara, J.P., 2010. Anti-biofilm activity of sub-inhibitory povidone-iodine concentrations against Staphylococcus epidermidis and Staphylococcus aureus. J. Orthop. Res. $28,1252-1256$.

Okuda, K.-I.,Zendo, T.,Sugimoto, S., Iwase, T., Tajima, A., Yamada, S., Sonomoto, K., Mizunoe, Y., 2013. Effects of bacteriocins on methicillin-resistant Staphylococcus aureus biofilm. Antimicrob. Agents Chemother. 57, 5572-5579.

Oliveira, A., de Lourdes Cunha, M., 2010. Comparison of methods for the detection of biofilm production in coagulase-negative staphylococci. BMC Res. Notes 3, 260.

Paiva, A.D.,Breukink, E., Mantovani, H.C., 2011. Role of lipid II and membrane thickness in the mechanism of action of the lantibiotic bovicin HC5. Antimicrob. Agents Chemother. 55, 5284-5293.

Palmer, J., Flint, S., Brooks, J., 2007. Bacterial cell attachment, the beginning of a biofilm. J. Ind. Microbiol. Biotechnol. 34, 577-588.

Pang, Y.Y.,Schwartz, J., Thoendel, M.,Ackermann, L.W.,Horswill, A.R., Nauseef, W.M., 2010. agr-Dependent interactions of Staphylococcus aureus USA300 with human polymorphonuclear neutrophils. J. Innate Immun. 2, 546-559.

Parsek, M.R.,Fuqua, C., 2004. Biofilms 2003: emerging themes and challenges in studies of surface-associated microbial life. J. Bacteriol. 186, 4427-4440.

Pimentel-Filho, N.J., Mantovani, H.C., Diez-Gonzalez, F., Vanetti, M.C.D., 2013. Inhibition of Listeria and Staphylococcus aureus by bovicin HC5 and nisin combination in milk. J. Agric. Sci. 5, 188-196.

Pimentel-Filho, N.J.,Mantovani, H.C.,Carvalho, A.F.,Dias, R.S.,Vanetti, M.C.D., 2014. Efficacy of bovicin HC5 and nisin combination against Listeria monocytogenes and Staphylococcus aureus in fresh cheese. Int. J. Food Sci. Technol. 49, 416-422.

Poutrel, B.,Lerondelle, C., 1978. Induced staphylococcal infections in the bovine mammary gland. Influence of the month of lactation and other factors related to the cow. Ann. Res. Vet. 9, 119-128.

Rasigade, J., Moulay, A., Lhoste, Y., Tristan, A., Bes, M., Vandenesch, F.O., Etienne, J., Lina, G., Laurent, F., Dumitrescu, O., 2011. Impact of sub-inhibitory antibiotics on fibronectinmediated host cell adhesion and invasion by Staphylococcus aureus. BMC Microbiol. $11,263-271$.

Rohde, H., Frankenberger, S.,Zähringer, U., Mack, D., 2010. Structure, function and contribution of polysaccharide intercellular adhesin (PIA) to Staphylococcus epidermidis biofilm formation and pathogenesis of biomaterial-associated infections. Eur. J. Cell Biol. 89, 103-111.
Sadowska, B.,Walencka, E.,Wieckowska-Szakiel, M.,Rozalska, B., 2010. Bacteria competing with the adhesion and biofilm formation by Staphylococcus aureus. Folia Microbiol. $55,497-501$.

Sandiford, S.,Upton, M., 2012. Identification, characterization, and recombinant expression of epidermicin NI01, a novel unmodified bacteriocin produced by Staphylococcus epidermidis that displays potent activity against staphylococci. Antimicrob. Agents Chemother. 56, 1539-1547.

Shafer, W.M., Iandolo, J.J., 1979. Genetics of staphylococcal enterotoxin B in methicillinresistant isolates of Staphylococcus aureus. Infect. Immun. 25, 902-911.

Simões, M., Simões, L.C., Vieira, M.J., 2010. A review of current and emergent biofilm control strategies. LWT-Food Sci. Technol. 43, 573-583.

Sinde, E., Carballo, J., 2000. Attachment of Salmonella spp. and Listeria monocytogenes to stainless steel, rubber and polytetrafluorethylene: the influence of free energy and the effect of commercial sanitizers. Food Microbiol. 17, 439-447.

Smith, K., Gould, K.A., Ramage, G., Gemmell, C.G., Hinds, J., Lang, S., 2010. Influence of tigecycline on expression of virulence factors in biofilm-associated cells of methicillin-resistant Staphylococcus aureus. Antimicrob. Agents Chemother. 54 380-387.

Solomakos, N.,Govaris, A., Koidis, P.,Botsoglou, N., 2008. The antimicrobial effect of thyme essential oil, nisin, and their combination against Listeria monocytogenes in minced beef during refrigerated storage. Food Microbiol. 25, 120-127.

Starcher, B., 2001. A ninhydrin-based assay to quantitate the total protein content of tissue samples. Anal. Biochem. 292, 125-129.

Ster, C., Gilbert, F.B., Cochard, T., Poutrel, B., 2005. Transcriptional profiles of regulatory and virulence factors of Staphylococcus aureus of bovine origin: oxygen impact and strain-to-strain variations. Mol. Cell. Probes 19, 227-235.

Teixeira, P., Lopes, Z., Azeredo, J., Oliveira, R., Vieira, M.J., 2005. Physico-chemical surface characterization of a bacterial population isolated from a milking machine. Food Microbiol. 22, 247-251.

Udompijitkul, P., Paredes-Sabja, D., Sarker, M.R., 2011. Inhibitory effects of nisin against Clostridium perfringens food poisoning and nonfood-borne isolates. J. Food Sci. 77 M51-M56.

Van Oss, C.J.,Giese, R.F., 1995. The hydrophilicity and hydrophobicity of clay minerals. Clay Clay Miner. 43, 474-477.

Vázquez-Sánchez, D.,Habimana, O.,Holck, A., 2013. Impact of food-related environmental factors on the adherence and biofilm formation of natural Staphylococcus aureus isolates. Curr. Microbiol. 66, 110-121.

Viana, E.S., Campos, M.E.M., Ponce, A.R., Mantovani, H.C., Vanetti, M.C.D., 2009. Biofilm formation and acyl homoserine lactone production in Hafnia alvei isolated from raw milk. Biol. Res. 42, 427-436.

Vogler, E.A., 1998. Structure and reactivity of water at biomaterial surfaces. Adv. Colloid Interf. Sci. 74, 69-117.

Winkelströter, L.K., Gomes, B.C.,Thomaz, M.R.S., Souza, V.M.,De Martinis, E.C.P., 2011 Lactobacillus sakei 1 and its bacteriocin influence adhesion of Listeria monocytogenes on stainless steel surface. Food Control 22, 1404-1407.

Xue, T.,You, Y.,Shang, F., Sun, B., 2012. Rot and Agr system modulate fibrinogen-binding ability mainly by regulating clfB expression in Staphylococcus aureus NCTC8325. Med. Microbiol. Immunol. 201, 81-92.

Yarwood, J.M., Bartels, D.J., Volper, E.M., Greenberg, E.P., 2004. Quorum sensing in Staphylococcus aureus biofilms. J. Bacteriol. 186, 1838-1850.

Zeraik, A.E.,Nitschke, M., 2010. Biosurfactants as agents to reduce adhesion of pathogenic bacteria to polystyrene surfaces: effect of temperature and hydrophobicity. Curr. Microbiol. 61, 554-559.

Zhu, X.,Zhao, Y.,Sun, Y.,Gu, Q., 2014. Purification and characterisation of plantaricin ZJ008, a novel bacteriocin against Staphylococcus spp. from Lactobacillus plantarum ZJ008. Food Chem. 165, 216-223. 